\title{
Papers
}

\section{Risk of prevalent HIV infection associated with incarceration among injecting drug users in Bangkok, Thailand: case-control study}

Aumphornpun Buavirat, Kimberly Page-Shafer, G J P van Griensven, J S Mandel, J Evans, J Chuaratanaphong, S Chiamwongpat, R Sacks, A Moss

\begin{abstract}
Objectives To identify risks for HIV infection related to incarceration among injecting drug users in Bangkok, Thailand.

Design Case-control study of sexual and parenteral exposures occurring before, during, and after the most recent incarceration.

Setting Metropolitan Bangkok.

Participants Non-prison based injecting drug users formerly incarcerated for at least six months in the previous five years, with documented HIV serostatus since their most recent release; $175 \mathrm{HIV}$ positive cases and 172 HIV negative controls from methadone clinics.

Main outcome measure Injection of heroin and methamphetamine, sharing of needles, sexual behaviour, and tattooing before, during, and after incarceration.

Results In the month before incarceration cases were more likely than controls to have injected methamphetamine and to have borrowed needles. More cases than controls reported using drugs $(60 \% v$ $45 \% ; \mathrm{P}=0.005)$ and sharing needles $(50 \% v 31 \%$; $\mathrm{P}<0.01)$ in the holding cell before incarceration. Independent risk factors for prevalent HIV infection included injection of methamphetamine before detention (adjusted odds ratio 3.3, 95\% confidence interval 1.01 to 10.7 ), sharing needles in the holding cell $(1.9,1.2$ to 3.0$)$, being tattooed while in prison (2.1, 1.3 to 3.4 ), and borrowing needles after release $(2.5,1.3$ to 4.4$)$.

Conclusions Injecting drug users in Bangkok are at significantly increased risk of HIV infection through sharing needles with multiple partners while in holding cells before incarceration. The time spent in holding cells is an important opportunity to provide risk reduction counselling and intervention to reduce the incidence of HIV.
\end{abstract}

\section{Introduction}

An estimated one million people in Thailand are infected with HIV, and the prevalence is highest among injecting drug users (30-40\%). ${ }^{1}$ The incidence of HIV, which declined from 57 per 100 person years of obser- vation in 1988 to 11 per 100 person years in 1991-2, is among the highest for any risk population in the country. ${ }^{2}$ High rates persist (5.8 per 100 person years of observation) despite widespread treatment with methadone and education to prevent HIV infection among injecting drug users in Bangkok. ${ }^{3}$

Incarceration has been associated with prevalent and incident HIV infection among injecting drug users, ${ }^{2-9}$ but little insight exists as to the timing of transmission. Associated risks include sharing needles and consensual and non-consensual sex. ${ }^{9-11}$ In a cohort study of injecting drug users in Bangkok, people who injected while incarcerated had a higher incidence of HIV infection (35.3 per 100 person years of observation) than those had been incarcerated but had not injected (11.3 per 100) and those who had not been incarcerated (4.9 per 100).

Formative work for this study revealed various relevant factors. ${ }^{12}$ Firstly, two thirds of injecting drug users in Bangkok reported injecting drugs four or more times a day during the month before their arrest. This can be characterised as a period of high intensity drug use, as 70\% of injecting drug users in a Bangkok cohort reported injecting less frequently. ${ }^{3}$ Secondly, injecting drug users who experience withdrawal symptoms will go to great lengths to alleviate them. Generally, in Bangkok, detainees are held at a police station for three to eight days before trial and sentencing. Many injecting drug users reported having acute withdrawal symptoms, borrowing needles, and injecting drugs with various unknown people during this holding period and that methods to clean injection equipment were not available.

We investigated two hypotheses: that the risk of HIV infection is increased before detention because of high intensity risk behaviour; and that the risk of HIV infection is increased during the holding period, which is likely to coincide with acute opiate withdrawal and increased risk behaviour. To investigate these hypotheses and define more fully the incarceration related risk of HIV infection we examined risk factors occurring before arrest, during the holding period, during incarceration, and immediately after release. The institutional review board of the University of California in San Francisco and the ethical research

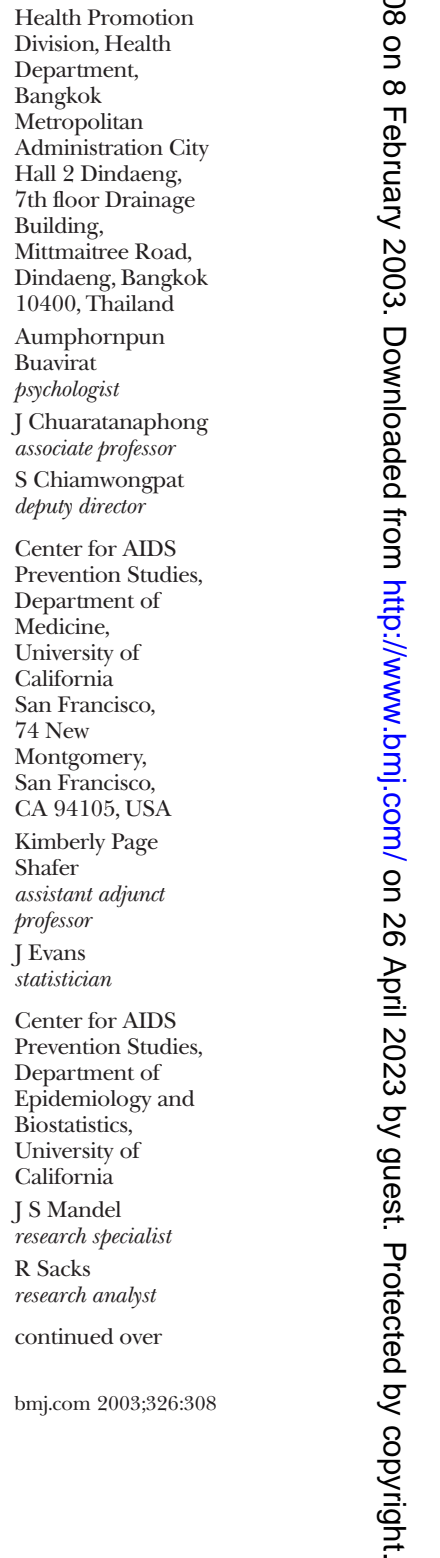


HIV/AIDS

Program, Thailand

MOPH-US CDC

Collaboration, DMS

Building 6, Ministry

of Public Health,

Nonthaburi 11000,

Thailand

G J P van Griensven

associate director for

science

Department of

Epidemiology and

Biostatistics,

University of

California

San Francisco,

995 Potrero

Avenue,

San Francisco,

CA 94110, USA

A Moss

professor in residence

Correspondence to:

K Page-Shafer

shafer@psg.ucsf.edu committee of the Bangkok Metropolitan Administration approved the study.

\section{Methods}

\section{Participants}

From August 2000 to January 2001 we recruited injecting drug users from 17 methadone clinics of the Bangkok Metropolitan Administration. These clinics serve most injecting drug users who seek treatment. We used consecutive sampling in each clinic to recruit male injecting drug users who had been incarcerated for at least six months during the previous five years. We defined a case as an HIV positive injecting drug user with a medical record documenting a negative HIV test within the five years before the most recent incarceration and HIV positive serostatus since the most recent release. Controls were HIV negative injecting drug users with current documentation. Initial contact occurred in the participating clinics, which advertised the study on posters in public areas. We approached potential participants privately, gave them detailed information about the study if they were interested and eligible, and obtained informed consent. We recruited and interviewed 175 cases and 172 controls.

We translated protocols and questionnaires from English to Thai, and independent reviewers verified

Table 1 Selected sociodemographic and behavioural characteristics and associations with HIV status in 347 previously incarcerated male injecting drug users in Bangkok, Thailand. Values are numbers (percentages) unless stated otherwise

\begin{tabular}{|c|c|c|c|}
\hline Characteristic & $\begin{array}{l}\text { Case participants } \\
(\mathrm{n}=175)\end{array}$ & $\begin{array}{c}\text { Control participants } \\
(\mathrm{n}=172)\end{array}$ & $\begin{array}{l}\text { Odds ratio } \\
(95 \% \mathrm{Cl})\end{array}$ \\
\hline \multicolumn{4}{|l|}{ Age (years): } \\
\hline $20-24$ & $43(25)$ & $55(32)$ & 1.0 \\
\hline $25-29$ & $40(23)$ & $40(23)$ & $1.3(0.7$ to 2.3$)$ \\
\hline $30-39$ & $65 / 172(38)$ & $53(31)$ & $1.6(0.9$ to 2.7$)$ \\
\hline$\geqslant 40$ & $24(14)$ & $24(14)$ & $1.3(0.6$ to 2.7$)$ \\
\hline \multicolumn{4}{|l|}{ Education: } \\
\hline Primary & $63(36)$ & $69(40)$ & 1.0 \\
\hline Secondary & $87(50)$ & $75(44)$ & $1.3(0.8$ to 2.0$)$ \\
\hline Post-secondary & $24(14)$ & $28(16)$ & 0.9 (0.5 to 1.8$)$ \\
\hline \multicolumn{4}{|l|}{ Employment status: } \\
\hline Student or unemployed & $101(58)$ & $92(53)$ & 1.0 \\
\hline Employed & $74(42)$ & $80(47)$ & $0.8(0.6$ to 1.3$)$ \\
\hline \multicolumn{4}{|l|}{ Marital status: } \\
\hline Single, divorced, or separated & $134(77)$ & $121(70)$ & 1.0 \\
\hline Married or cohabitating & $41(23)$ & $51(30)$ & $0.7(0.5$ to 1.2$)$ \\
\hline \multicolumn{4}{|l|}{ Living situation in previous six months: } \\
\hline With parents or relatives & $141(81)$ & $133(77)$ & 1.0 \\
\hline In own or rented property & $23(13)$ & $27(16)$ & 0.8 (0.4 to 1.5$)$ \\
\hline Other & $11(6)$ & $12(7)$ & $0.9(0.4$ to 2.0$)$ \\
\hline $\begin{array}{l}\text { Median (interquartile range) duration of } \\
\text { injected drug use (years) }\end{array}$ & $9(7-13)$ & $8(6-13)$ & $0.03^{*}$ \\
\hline \multicolumn{4}{|c|}{ Years in treatment at Bangkok Metropolitan Administration clinics: } \\
\hline $0-2$ & $27(16)$ & $47(28)$ & 1.0 \\
\hline $3-6$ & $55(31)$ & $59(34)$ & $1.6(0.9$ to 3.0$)$ \\
\hline$>6$ & $93(53)$ & $65(38)$ & $2.5(1.4$ to 4.4$)$ \\
\hline $\begin{array}{l}\text { Median (interquartile range) duration of } \\
\text { most recent prison stay (months) }\end{array}$ & $12(7-16)$ & $12(8-18)$ & $0.71^{*}$ \\
\hline \multicolumn{4}{|l|}{ Total times in prison: } \\
\hline 1 & $41(23)$ & $40(23)$ & 1.0 \\
\hline$\geqslant 2$ & $134(77)$ & $132(77)$ & $1.0(0.6$ to 1.6$)$ \\
\hline \multicolumn{4}{|c|}{ Charged with drug possession in most recent prison stay: } \\
\hline No & $24(14)$ & $33(19)$ & 1.0 \\
\hline Yes & $151(86)$ & $139(81)$ & $1.5(0.8$ to 2.7$)$ \\
\hline
\end{tabular}

page 2 of 5 their content. During structured interviews, we asked participants about demographic characteristics and about injecting and sexual risk behaviours before, during, and immediately after incarceration.

Statistical analysis

Summary statistics included frequency tables for categorical variables and medians and interquartile ranges for continuous variables. We did bivariate analyses of associations with HIV status for demographic variables, injection drug use, and sexual risk variables. We used multiple logistic regression analysis to identify independent predictors of prevalent HIV infection. We considered variables for inclusion in multifactorial models if we found them to be significant in bivariate analyses or considered them to be potential confounders on the basis of biological or behavioural inference. We used backward stepwise selection, entering variables with significance levels of $\mathrm{P} \leqslant 0.10$ into the model and excluding those with $P \geqslant 0.20$. We identified no significant interaction effects. The final model included variables significant at $\mathrm{P} \leqslant 0.05$ as well as a variable to control for time of exposure (duration of injected drug use). We used the final multifactorial model to obtain estimates of adjusted population attributable fraction and 95\% confidence intervals by using an approach based on unconditional logistic regression (aflogit procedures; StataCorp, College Station, TX). ${ }^{13} 14$

\section{Results}

The 175 cases and 172 controls had a median age of 29 (interquartile range 25-36) years; all were Thai citizens; 84\% resided in Bangkok; and 48\% were unemployed. The demographic characteristics of cases and controls were similar (table 1). Cases had a higher median number of years of injected drug use than controls $(9.2(7-13)$ v $8.0(6-13), \mathrm{P}<0.05)$ and more months in drug treatment (84 $v 67$ months, $\mathrm{P}<0.01$ ). We found no differences in length of latest prison stay, frequency of incarceration, or time since the most recent release from prison (median 36 (22-68) months).

\section{Injection risk}

Before detention-More cases than controls reported having injected methamphetamine $(9 \% v 2 \%, \mathrm{P}<0.01)$ and having injected combinations of heroin and methamphetamine $(15 \% v 8 \%, \mathrm{P}<0.05)$ during the month before arrest (table 2). Cases were also more likely to recall having borrowed needles during that period $(46 \%$ v $28 \%, \mathrm{P}<0.01)$.

While in the holding cell-More cases than controls reported having used drugs in the holding cell $(60 \% v$ $45 \%, \mathrm{P}<0.01)$ and having injected heroin $(51 \% v 36 \%$, $\mathrm{P}<0.05$ ) (table 2). No differences existed between cases and controls in the number of times they used drugs while in the holding cell (3 (1-5) $v 2$ (1-3), $\mathrm{P}=0.58)$. More cases than controls had shared needles in the holding cell $(50 \%$ v 31\%, $\mathrm{P}<0.01)$; among men who shared needles, cases reported sharing with a higher median number of people (5 (4-8) $v 4(2-7), \mathrm{P}<0.05)$. Cases and controls did not differ with respect to where they obtained drugs while in the police holding cells $(34 \%(\mathrm{n}=61)$ from other prisoners; $30 \%$ (54) smuggled in from outside). 
Table 2 Injection drug use behaviours "one month before detention"* and "in police holding cell"* and associations with HIV status among 347 male injecting drug users in Bangkok, Thailand. Values are numbers (percentages) unless stated otherwise

\begin{tabular}{|c|c|c|c|c|c|c|}
\hline \multirow[b]{2}{*}{ Behaviour } & \multicolumn{3}{|c|}{ One month before detention } & \multicolumn{3}{|c|}{ While in police holding cell } \\
\hline & $\begin{array}{l}\text { Case participants } \\
\qquad(\mathrm{n}=175)\end{array}$ & $\begin{array}{c}\text { Control } \\
\text { participants } \\
(\mathrm{n}=172)\end{array}$ & $\begin{array}{l}\text { Odds ratio } \\
(95 \% \text { CI) }\end{array}$ & $\begin{array}{l}\text { Case participants } \\
\qquad(\mathrm{n}=175)\end{array}$ & $\begin{array}{c}\text { Control } \\
\text { participants } \\
(\mathrm{n}=172)\end{array}$ & $\begin{array}{l}\text { Odds ratio } \\
(95 \% \mathrm{Cl})\end{array}$ \\
\hline \multicolumn{7}{|l|}{ Used drugs: } \\
\hline No & $2(1)$ & $2(1)$ & 1.0 & $70(40)$ & $95(55)$ & 1.0 \\
\hline Yes & $173(99)$ & $170(99)$ & $1.0(0.1$ to 7.3$)$ & $105(60)$ & $77(45)$ & 1.9 (1.2 to 2.8$)$ \\
\hline \multicolumn{7}{|l|}{ Injected heroin: } \\
\hline No & $7(4)$ & $12(7)$ & 1.0 & $86(49)$ & $110(64)$ & 1.0 \\
\hline Yes & $168(96)$ & $160(93)$ & $1.8(0.7$ to 4.7$)$ & $89(51)$ & $62(36)$ & 1.8 (1.2 to 2.8$)$ \\
\hline \multicolumn{7}{|l|}{ Injected methamphetamine: } \\
\hline No & $160(91)$ & $168(98)$ & 1.0 & $172(98)$ & $168(98)$ & 1.0 \\
\hline Yes & $15(9)$ & $4(2)$ & $3.9(1.3$ to 12.1$)$ & $3(2)$ & $4(2)$ & 0.7 (0.2 to 3.3$)$ \\
\hline \multicolumn{7}{|c|}{ Injected heroin-methamphetamine combination: } \\
\hline No & $148(85)$ & $158(92)$ & 1.0 & $170(97)$ & $171(99)$ & 1.0 \\
\hline Yes & $27(15)$ & $14(8)$ & $2.1(1.0$ to 4.0$)$ & $5(3)$ & $1(1)$ & $5.0(0.6$ to 43.5$)$ \\
\hline \multicolumn{7}{|l|}{ Injected sedative: } \\
\hline No & $146(83)$ & $151(88)$ & 1.0 & $171(98)$ & $169(98)$ & 1.0 \\
\hline Yes & $29(17)$ & $21(12)$ & $1.4(0.8$ to 2.6$)$ & $4(2)$ & $3(2)$ & $1.3(0.3$ to 6.0$)$ \\
\hline \multicolumn{7}{|l|}{ Borrowed or shared needles: } \\
\hline No & $94(54)$ & $124(72)$ & 1.0 & $88(50)$ & $118(69)$ & 1.0 \\
\hline Yes & $81(46)$ & $48(28)$ & $2.2(1.4$ to 3.5$)$ & $87(50)$ & $54(31)$ & $2.2(1.4$ to 3.3$)$ \\
\hline \multicolumn{7}{|c|}{ If yes, No of people borrowed or shared needles with or from: } \\
\hline 1 & $33(41)$ & $27(56)$ & 1.0 & $2(2)$ & $5(9)$ & 1.0 \\
\hline$\geqslant 2$ & $48(59)$ & $21(44)$ & $1.9(0.9$ to 3.9$)$ & $85(98)$ & $49(91)$ & $4.3(0.8$ to 23.2$)$ \\
\hline Median (interquartile range) No of & $6(2-10)$ & $5(2-10)$ & $0.64 \dagger$ & NA & NA & NA \\
\hline
\end{tabular}

times borrowed needles

$\mathrm{NA}=$ not applicable

${ }^{*}$ Most recent incarceration.

$\dagger P$ value (Kruskal-Wallis test).

While in prison-Cases and controls reported similar heroin and methamphetamine injection practices while in prison (table 3). Cases were more likely than controls to report using non-injection sedatives $(11(6 \%) \cup 2(1 \%), \mathrm{P}<0.05)$ and to recall injecting drugs with other people $(33 \% v 22 \%, \mathrm{P}<0.05)$. Among men who injected, however, no differences existed in the median number of injecting partners $(8(5-10)$ v 5 (3-10), $\mathrm{P}=0.45)$.

After release-A higher proportion of cases than controls reported injecting sedatives $(11 \%$ v $5 \%$, $\mathrm{P}<0.05$ ) but not other drugs in the 30 day period after release from prison (table 3 ). A higher proportion of cases reported borrowing needles $(31 \%$ v $13 \%$, $\mathrm{P}<0.05$ ), but no differences existed in the median number of times they did this or the number of people they borrowed needles from.

\section{Other risks}

Sexual behaviour-Cases and controls did not differ with respect to reported sexual behaviour during any of the prison related time periods. Twenty four (14\%) cases and 20 (12\%) controls reported having anal sex during incarceration; no differences existed in the number of partners or the proportion of insertive or receptive partners (data not shown).

Tattooing-Cases were significantly more likely than controls to be tattooed during incarceration $(59 \% v$ $42 \%, \mathrm{P}<0.05$; table 3 ), but the number of tattoos did not differ (2 (1-4.5) $v 3(2-5), \mathrm{P}=0.16)$, and nor did the proportion of cases and controls who reported sharing tattooing needles $(89(85 \%)$ v $55(75 \%) ; \mathrm{P}=0.12)$.

\section{Independent risk factors for prevalent HIV infection}

Variables independently associated with prevalent HIV infection (table 4) included exposures both in and out of prison: use of methamphetamine during the month before detention (adjusted odds ratio 3.3, 95\% confidence interval 1.01 to 10.7 ), sharing needles in the holding cell before incarceration (1.9, 1.2 to 3.0), borrowing needles in the month after release from prison $(2.5,1.3$ to 4.4 ), and being tattooed while in prison $(2.1,1.3$ to 3.4$)$. The population attributable fraction (table 4) for being tattooed while in prison was the highest $(17.1 \%)$, reflecting the high prevalence of the risk factor $(52 \%)$. Injecting methamphetamine before incarceration had the lowest population attributable fraction $(2.5 \%)$, whereas sharing needles in the holding cell and after release from prison, which were more prevalent, had higher population attributable fraction estimates $(11.1 \%$ and $8.6 \%)$.

\section{Discussion}

\section{Risk factors for HIV infection}

To increase understanding of injecting drug users' risk of HIV infection in relation to periods of incarceration, we compared risk factors among HIV positive and HIV negative injecting drug users before, during, and after incarceration. We found that prevalent HIV infection was associated with risky injecting both before and after prison: injection of methamphetamine before detention, sharing of needles while in a holding cell before incarceration, and borrowing needles during the period after release from prison. Injected drug use was highly prevalent in holding cells: $51 \%$ of cases 
Table 3 Injection drug use behaviours "in prison"* and "one month after release"* and associations with HIV status in 347 previously incarcerated male injecting drug users in Bangkok, Thailand. Values are numbers (percentages) unless stated otherwise

\begin{tabular}{|c|c|c|c|c|c|c|}
\hline \multirow[b]{2}{*}{ Behaviour } & \multicolumn{3}{|c|}{ While in prison } & \multicolumn{3}{|c|}{ One month after release } \\
\hline & $\begin{array}{l}\text { Case participants } \\
\qquad(n=175)\end{array}$ & $\begin{array}{l}\text { Control } \\
\text { participants } \\
(\mathrm{n}=172)\end{array}$ & $\begin{array}{l}\text { Odds ratio } \\
(95 \% \mathrm{CI})\end{array}$ & $\begin{array}{l}\text { Case participants } \\
\qquad(\mathrm{n}=175)\end{array}$ & $\begin{array}{c}\text { Control } \\
\text { participants } \\
(\mathrm{n}=172)\end{array}$ & $\begin{array}{l}\text { Odds ratio } \\
(95 \% \mathrm{CI})\end{array}$ \\
\hline \multicolumn{7}{|l|}{ Used drugs: } \\
\hline No & $103(59)$ & $113(66)$ & 1.0 & NA & NA & NA \\
\hline Yes & $72(41)$ & $59(34)$ & $1.3(0.9$ to 2.0$)$ & & & \\
\hline \multicolumn{7}{|c|}{ Injected heroin: } \\
\hline No & $120(69)$ & $135(78)$ & 1.0 & $12(7)$ & $25(15)$ & 1.0 \\
\hline Yes & $55(31)$ & $37(22)$ & $1.7(1.0$ to 2.7$)$ & $163(93)$ & $147(85)$ & $2.3(1.1$ to 4.8$)$ \\
\hline \multicolumn{7}{|c|}{ Injected methamphetamine: } \\
\hline No & $172(98)$ & $169(98)$ & 1.0 & $167(95)$ & $166(97)$ & 1.0 \\
\hline Yes & $3(2)$ & $3(2)$ & $1.0(0.2$ to 4.9$)$ & $8(5)$ & $6(3)$ & $1.3(0.5$ to 3.9$)$ \\
\hline \multicolumn{7}{|c|}{ Injected heroin-methamphetamine combination: } \\
\hline No & $171(98)$ & $171(99)$ & 1.0 & $157(90)$ & $161(94)$ & 1.0 \\
\hline Yes & $4(2)$ & $1(1)$ & $4.0(0.4$ to 36.2$)$ & $18(10)$ & $11(6)$ & 1.7 (0.8 to 3.7$)$ \\
\hline \multicolumn{7}{|c|}{ Injected sedative: } \\
\hline No & $173(99)$ & $170(99)$ & 1.0 & $155(89)$ & $163(95)$ & 1.0 \\
\hline Yes & $2(1)$ & $2(1)$ & $1.0(0.1$ to 7.1$)$ & $20(11)$ & $9(5)$ & 2.3 (1.0 to 5.3$)$ \\
\hline \multicolumn{7}{|c|}{ Injected drugs with other people: } \\
\hline No & $117(67)$ & $135(78)$ & 1.0 & NA & NA & NA \\
\hline Yes & $58(33)$ & $37(22)$ & $1.8(1.1$ to 2.9$)$ & & & \\
\hline \multicolumn{7}{|c|}{ Borrowed needles: } \\
\hline No & NA & NA & NA & $121(69)$ & $149(87)$ & 1.0 \\
\hline Yes & & & & $54(31)$ & $23(13)$ & $2.9(1.7$ to 5.0$)$ \\
\hline \multicolumn{7}{|c|}{ Been tattooed: } \\
\hline No & $71(41)$ & $99(58)$ & 1.0 & NA & NA & NA \\
\hline Yes & $104(59)$ & $73(42)$ & $2.0(1.3$ to 3.0$)$ & & & \\
\hline
\end{tabular}

$\mathrm{NA}=$ not applicable.

${ }^{*}$ Most recent incarceration.

reported injecting heroin during approximately one week in a holding cell, compared with $31 \%$ during a median incarceration time of 52 weeks in prison. Being tattooed was the only factor during incarceration that was associated with prevalent HIV infection.

The high risk associated with injection of methamphetamine is important for several reasons. Use of methamphetamine is increasing rapidly throughout Thailand, ${ }^{15}$ and it may become a more predominant hazard for HIV infection, as in other parts of the world. ${ }^{16}{ }^{17}$ Use of methamphetamine may also be a marker for the most risky injecting behaviours. Our results did not support the hypothesis that the period before arrest is characterised by high intensity drug use or "bingeing." On the contrary, the relevant drug and injection risk associations were limited to the time spent in the holding cell and after release, both periods of high vulnerability (the first a period of withdrawal and the second a period of reduced drug tolerance and risk of drug overdose). ${ }^{18}$

Sharing needles while in the police holding cell was an independent risk factor for prevalent HIV infection.

Table 4 Independent associations with HIV-1 infection (multifactorial analysis) and associated population attributable fractions among 347 male injecting drug users in Bangkok, Thailand

\begin{tabular}{|c|c|c|}
\hline Characteristic & $\begin{array}{l}\text { Adjusted odds ratio } \\
(95 \% \mathrm{Cl})\end{array}$ & $\begin{array}{c}\text { Adjusted population } \\
\text { attributable fraction } \\
\qquad(95 \% \mathrm{Cl})\end{array}$ \\
\hline Years of injecting (per year) & $1.0(0.99$ to 1.1$)$ & $0.104(-0.09$ to 0.26$)$ \\
\hline $\begin{array}{l}\text { Used methamphetamine one month before detention } \\
\text { (injected } v \text { no use or not an intravenous drug user) }\end{array}$ & $3.3(1.01$ to 10.7$)$ & $0.025(0.004$ to 0.05$)$ \\
\hline Shared needles in holding cell (yes $v$ no) & $1.9(1.2$ to 3.0$)$ & $0.111(0.02$ to 0.19$)$ \\
\hline Tattooed in prison (yes $v$ no) & $2.1(1.3$ to 3.4$)$ & 0.171 (0.06 to 0.27$)$ \\
\hline Borrowed needles one month after release (yes $v$ no) & 2.5 (1.3 to 4.4$)$ & $0.086(0.03$ to 0.14$)$ \\
\hline
\end{tabular}

Although previous studies have indicated that sharing injecting equipment while incarcerated is a key risk factor for HIV infection in Thailand, ${ }^{3}$ the exact time of infection could not be determined in these studies. To our knowledge, our study is the first to pinpoint excess risk during the holding period before incarceration. This finding confirms our hypothesis that high risk exposures such as borrowing needles and injecting drugs with multiple partners in the holding cell are probably attempts to alleviate the severe symptoms of drug withdrawal. ${ }^{12}$ A possible confounding factor is that prisoners in holding cells in Bangkok may have more opportunity to inject owing to lower security at this stage of their remand.

We found no differences in drug use by cases and controls during time in prison. Being tattooed, although common, was associated with being HIV positive. Tattooing has recently been shown to be associated with prevalent HIV infection among Thai fishermen. ${ }^{19}$ We hypothesise that tattooing in prison conditions occurs in unhygienic conditions. Whereas tattooing is not generally recognised as a risk factor for HIV, the possibility remains. ${ }^{20}$ Alternatively, it may be an indicator of another unmeasured exposure.

Attributable fractions estimate the potential for preventive interventions by linking information about the prevalence of the exposure with an associated measure of excess risk. Although injecting methamphetamine presents a significant risk for HIV infection, the higher prevalence of sharing needles and tattooing result in larger population attributable fraction estimates. Thus prevention and control of HIV infection among injecting drug users in Bangkok must focus not only on reducing injection of methamphet- 


\section{What is already known on this topic}

The incidence of HIV in Thailand is highest among injecting drug users in Bangkok

Incarceration is a risk factor for incident HIV infection among Thai injecting drug users

\section{What this study adds}

Injecting drug users are at increased risk of HIV infection from sharing needles with multiple partners while in police holding cells before incarceration

Other risk factors include injecting methamphetamine before imprisonment, being tattooed while imprisoned, and sharing needles after release

amine but especially on parenteral exposures, both inside and outside prison.

\section{Limitations and strengths of the study}

Limitations of the study include possible recall bias: participants were asked to recollect many events over a long period of time, which, in addition to the added influence of drugs, may have influenced the accuracy of their responses. Such a bias would result in an underestimation of the risk associations, as a result of underreporting of sensitive behaviours. Also, cases could have selectively recalled exposures related to their infection status and may have differentially reported risk, resulting in overestimation of excess risk. Lastly, despite restricting eligibility to people who had been HIV negative before their most recent incarceration, we have no accurate way of ascertaining when seroconversion occurred.

The design of this study aimed to ensure that cases and controls came from the same reference population over a corresponding time period. Another strength was the high quality of the Bangkok Metropolitan Administration medical records used to ascertain HIV status relative to incarceration. Participants in this study were comparable to other populations of injecting drug users studied in Bangkok.

\section{Targeting HIV prevention}

Despite increased risk of HIV and recommendations to make harm reduction measures accessible inside prison, ${ }^{8122}$ prevention activities, including clean needles, condoms, and methadone maintenance, are rare in prisons. ${ }^{23}$ Counselling and drug detoxification should also be targeted to injecting drug users in holding cells. Barriers to prison based HIV interventions can be overcome by developing collaborative prevention partnerships between public health and law enforcement. ${ }^{24}$ As injecting drug users tend to serve short prison terms owing to the petty nature of their crimes, ${ }^{12}$ most will soon return to society. Both prisoners and people in close contact with them after their release will benefit from targeted comprehensive efforts to prevent HIV infection.

Contributors: $\mathrm{AB}$ proposed the idea for and designed the study, designed the questionnaire, oversaw data collection, and drafted the manuscript. KP-S proposed the idea for and designed the study, analysed and interpreted the data, and drafted and revised the manuscript. GJPvanG contributed to the idea for the study, interpretation of the data, and the writing and critical revisions of the paper. JSM contributed to administrative and material support, interpretation of data, and revisions of the manuscript.JE conducted analyses and contributed to the writing and revisions of the paper. JC and SC participated in acquisition and analysis of the data, translation of questionnaires and protocols, administrative and technical support, and revisions of the paper. RS participated in acquisition of the data and administrative and technical support. AM contributed to the idea for and design of the study, design of the questionnaire, interpretation of data, and the writing and critical revisions of the paper. All authors approved the final version of the manuscript. KPS is the guarantor.

Funding: NIH/NIMH (5 P50 MH42459). AB, JC, and SC were supported by the Bangkok Metropolitan Administration. KP-S, JSM, AM, and RS were supported by NIH/NIMH (5 P50 MH42459). GJPvanG was supported by the HIV/AIDS Program, Thailand MOPH-US CDC Collaboration.

Competing interests: None declared.

1 Surasiengsunk S, Kiranandana S, Wongboonsin K, Garnett GP, Anderson $\mathrm{RM}$, van Griensven GJ. Demographic impact of the HIV epidemic in Thailand. AIDS 1998;12:775-84.

2 Kitayaporn D, Uneklabh C, Weniger BG, Lohsomboon P, Kaewkungwal J, Morgan WM, et al. HIV-1 incidence determined retrospectively among drug users in Bangkok, Thailand. AIDS 1994;8:1443-50.

3 Vanichseni S, Kitayaporn D, Mastro TD, Mock PA, Raktham S, Des Jarlais DC, et al. Continued high HIV-1 incidence in a vaccine trial preparatory cohort of injection drug users in Bangkok, Thailand. AIDS 2001;15:397405 .

4 Choopanya K, Vanichseni S, Des Jarlais DC, Plangsringarm K, Sonchai W, Carballo M, et al. Risk factors and HIV seropositivity among injecting drug users in Bangkok. AIDS 1991;5:1509-13.

5 Brewer TF, Vlahov D, Taylor E, Hall D, Munoz A, Polk BF. Transmission of HIV-1 within a statewide prison system. AIDS 1988;2:363-7.

6 Taylor A, Goldberg D, Emslie J, Wrench J, Gruer L, Cameron S, et al. Outbreak of HIV infection in a Scottish prison. BMJ 1995;310:289-92

7 Diaz RS, Kallas EG, Castelo A, Rawal BD, Busch MP. Use of a new "lesssensitive enzyme immunoassay" testing strategy to identify recently infected persons in a Brazilian prison: estimation of incidence and epidemiological tracing. AIDS 1999;13:1417-8.

8 Dolan KA, Wodak A. HIV transmission in a prison system in an Australian state. Med J Aust 1999;171:14-7.

9 Edwards A, Curtis S, Sherrard J. Survey of risk behaviour and HIV prevalence in an English prison. Int J STD AIDS 1999;10:464-6.

10 Allwright S, Bradley F, Long J, Barry J, Thornton L, Parry JV. Prevalence of antibodies to hepatitis B, hepatitis C, and HIV and risk factors in Irish prisoners: results of a national cross sectional survey. BMJ 2000;321:78 82.

11 Mahon N. New York inmates' HIV risk behaviors: the implications for prevention policy and programs. Am J Public Health 1996;86:1211-5

12 Buavirat A, Sacks R, Chiamwongpat S. HIV risk behaviors during incarceration among intravenous drug users in Bangkok, Thailand: a qualitative approach. AIDS Public Policy (in press).

13 Bruzzi P, Green SB, Byar DP, Brinton LA, Schairer C. Estimating the population attributable risk for multiple risk factors using case-control data. Am J Epidemiol 1985;122:904-14.

14 Benichou J, Gail MH. Variance calculations and confidence intervals for estimates of the attributable risk based on logistic models. Biometric 1990;46:991-1003.

15 Sattah MV, Supawitkul S, Dondero TJ, Kilmarx PH, Young NL, Mastro TD, et al. Prevalence of and risk factors for methamphetamine use in northern Thai youth: results of an audio-computer-assisted selfinterviewing survey with urine testing. Addiction 2002;97:801-8.

$16 \mathrm{Kral}$ AH, Bluthenthal RN, Booth RE, Watters JK. HIV seroprevalence among street-recruited injection drug and crack cocaine users in 16 US municipalities. Am J Public Health 1998;88:108-13.

17 Chesney MA, Barrett DC, Stall R. Histories of substance use and risk behavior: precursors to HIV seroconversion in homosexual men. Am J Public Health 1998;88:113-6.

18 Frischer M, Goldberg D, Rahman M, Berney L. Mortality and survival among a cohort of drug injectors in Glasgow, 1982-1994. Addiction 1997;92:419-27.

19 Entz AT, Ruffolo VP, Chinveschakitvanich V, Soskolne V, van Griensven GJ. HIV-1 prevalence, HIV-1 subtypes and risk factors among fishermen in the Gulf of Thailand and the Andaman Sea. AIDS 2000;14:1027-34.

20 Braithwaite RL, Stephens T, Sterk C, Braithwaite K. Risks associated with tattooing and body piercing. J Public Health Policy 1999;20:459-70

21 Gaiter J, Doll LS. Improving HIV/AIDS prevention in prisons is good public health policy. Am J Public Health 1996;86:1201-3.

22 Association of State and Territorial Health Officials. Why public health should go to jail. Washington, DC: ASTHO, 1999:1-2.

23 Dolan K, Wodak A, Penny R. AIDS behind bars: preventing HIV spread among incarcerated drug injectors. AIDS 1995;9:825-32.

24 Grinstead OA, Zack B, Faigeles B. Collaborative research to prevent HIV among male prison inmates and their female partners. Health Educ Beha 1999;26:225-38

(Accepted 4 November 2002) 